\title{
Muslims in Pre- and Post-9/11 Contexts
}

\author{
Md Abu Shahid Abdullah \\ Department of English Literature \\ Otto-Friedrich University Bamberg, Germany
}

Received: 05-05-2015

Accepted: 15-07-2015

Published: 31-07- 2015

doi:10.7575/aiac.ijclts.v.3n.3p.52

URL: http://dx.doi.org/10.7575/aiac.ijclts.v.3n.3p.52

\begin{abstract}
Muslims have never ceased to be important for the West and have been depicted in vilifying and stereotypical manners in western literature and films. However, after the tragic event of 9/11, a dramatic change has been observed in the world's focus towards Muslims. Although stereotypes and discriminatory actions were nothing new to Muslims, the post-9/11 backlash was absolutely terrible and heartbreaking. People have started to consider Muslims either terrorists or sympathetic to terrorists, and they have been suspected and distrusted. Lots of books, articles and films have depicted Muslims in a derogatory and extreme manner. Pre-9/11 Hollywood movies True Lies and The Siege explicitly show the stereotypical attitude of the West to Muslims while post-9/11 novels like The Reluctant Fundamentalist by Mohsin Hamid and Once in a Promised Land by Laila Halaby depict the plight and predicament of Muslims in America. The article aims to depict the stereotypical, vilifying and antagonistic attitudes of the West to Arabs and Muslims in both pre- and post- $9 / 11$ era. It also aims to prove that the depiction is highly motivated by the media, western authorities and the West's desire for social, cultural and political dominance over the East.
\end{abstract}

Keywords: Orientalism, Others, Terrorism, Media

\section{Introduction}

Muslims have often been viewed in stereotypical ways by Western culture. The media in particular have often denigrated Muslims and Easterners by portraying them as marginal and insignificant. People's ideas are shaped by the ways Muslims and Easterners appear in the media, novels and films. The origins of this defamation were described by Edward Said in his book Orientalism (1978) where he pointed out how Orientalism contributed to the formation of the dichotomy between the West and the East, whereby the first controls the second, and where the East was portrayed or identified as the West's 'Other' and the source of its identity. Said also argues that, the representation of Muslims was entangled with military, economic and political strategies of Western countries.

The present study is interested in the longer history of this so-called clash of civilizations because it underwrites the representation of Muslim characters in contemporary films, and because it helps us understand the dynamic of Hollywood morality and hero aesthetic when it involves characters of Middle Eastern origin often perceived as distasteful and on whom projections of evil and fear can easily be imposed. Western media reports contain a continuous distorted image of Arabs and Muslims; false stereotype of Muslims and Islam is very much common in the Western media by every possible way. Often Arabs and Muslims are confused as same entity and are considered as antidemocratic, irrational, hot-tempered, barbaric, uncultured, lustful, and so on. The media distort many Islamic concepts such as prayer, recitation, and ablution to achieve their aim. They even fail to understand the true meaning of the word 'Jihad' and wrongly associate it with violent acts and wars while 'Jihad' can be any kind of internal or external struggle Muslims have to face every day.

The traumatic event of 9/11 has a strong impact on Westerners' attitudes towards Islam and Muslims. This small community suddenly came under limelight, and became visible and exposed to the public glare. Muslims started to be suspected as either terrorists or sympathetic to terrorism and terrorists, and were distrusted. This particular event marked the beginning of a new era where Muslims became the victims of backlash. For many, this tragic event paved the way for a period of hate crimes, profiling, and discrimination. Muslims were viewed as violent, aggressive, and antiAmerican, and the media were hugely responsible for shaping people's attitude towards them. Lots of novels were written and films were made on the theme of terrorism where Muslims were directly associated with terrorist activities. Some Muslim writers also wrote novels on their sense of religious and national identity which can be considered a response to the portrayal of Muslims by non-Muslim writers.

The first part of the present study focuses on the way Muslims were viewed by Westerners in pre-9/11 era. This research attempts to explore the reasons behind the stereotypical perception and shed light on the role of media behind this perception. It analyzes two pre-9/11 films: True Lies (1994) and The Siege (1998) and shows the detrimental and abusive portrayal of Arabs and Muslims. The second part of the paper investigates the terrible aftermath of Twin Towers attack on Muslims, and the changing attitudes towards them across America. It explores more about the wretched and inhuman condition of and Jihadist perception about Muslims in post-9/11 period. The present study also 
analyzes two post-9/11 novels: Once in a Promised Land (2007) by Laila Halaby and The Reluctant Fundamentalist (2007) by Mohsin Hamid and examines the consequences of 9/11 on Muslims in these selected works.

\section{Perception and Depiction of Muslims in Pre-9/11 Era}

Muslims have long been viewed by the West as stereotypes, which is obvious from their depiction in novels and films. Islam and Muslims are historically looked down upon by the West and stereotypes about Islam are not new to Western culture. This problem can be traced back 1400 years. At that time, Islam and Christianity were involved in the 'crusades' in the 1100s, and in the Ottoman and Moorish control in Europe. Islam started to threaten the position of the Christian Church and the ruling class. Western elites, mainly the governments and the churches, became highly involved in making sure that negative images about Islam were presented to their counter parts. Lots of battles took place against Islam, and war of words was initiated to prevent Islam from having any converts or sympathizers in the West. These kinds of actions and attitudes that the West possessed long ago seem to reverberate even today.

Edward Said, in his book Orientalism, mentioned that Orientalist work or the representation of the East was intimately entangled with the military, economic and political strategies of western countries. This work was also pertinent to literature, where Said provided a significant framework for Orientalism as practised in the West, with particular attention to the United States. However, he presents no specific criteria for the evolution of this negative image in the western media, chiefly in cinema, where some examples would have been welcome.

Said presented Orientalism as a multifaceted discourse focusing on the characterization of Arabs and Muslims according to some major dogmas, the first of which was to create a systematic difference that distinguished the civilized West from the backward East. This can be found, for example, in American films, especially the earliest productions where Egyptian Arabs are ridiculously portrayed as villains, cowardly, barbaric, dreadful, and evil. Later, Hollywood proceeded to represent Muslims not only as villains but also as lacking in morals and honor; it is obvious in movies like the Hostage series (1986-1992) where we see Arabs brutally raping and killing not only young girls but also mothers and the elderly on board. The most important point is that these Arabs really need, and will still need American assistance is represented in Three Kings (1999) where the American Army protects Iraqi civilians from their oppressive government (Arti, 2007, p. 2). Said shows that Arabic culture was decisively distorted by mixing the myth with the heritage, and the reality with history as portrayed in early Hollywood productions in terms of harems, magic lamps, desert dwellers, mastery and decadence, irrationality and backwardness (p. 3). Finally, Orientalism produces the idea that the Orient is a terrifying place that should be controlled, and this is presented clearly in Hollywood movies where Arab associations are considered a threat both for the West and the East. Thus, Said states that the relationship between the Orient and the Occident is that of imperialism, domination and hegemony, and it is hegemony or rather the result of cultural hegemony at work that gives Orientalism its durability and the strength (Said, 1978, p. 7).

Suleiman (1999) asserts that Hollywood's stereotype of Muslims purposefully persists with the concept of 'Otherness' in order to segregate them as primitive, backward and dangerous people that need, and will continue to nee American help. He believes that the US has used propaganda to facilitate its political objectives inquiring why Hollywood for more than a century has been perpetuating a hostile relationship with most of the Middle Eastern world (qtd. in Arti, 2007 , p. 5). He concludes that this has been purposeful and highly motivated, especially when it comes to the ArabIsraeli conflict. In addition, he traces the origin of American stereotypes of the Middle East to a time when the U.S. superpower and oil interests clashed with Arab Nationalism and collided with the Iranian revolution and Islamic influence (p. 5).

The negative portrayal of Muslims in the media began intensively after World War II, and in particular from the 1960s onwards. Different issues, such as huge Muslim migration to Western countries, Israel-Palestine conflict, independence of several African countries after the Second World War, overlapping between religious and political interest, and so on might have been responsible for this increased negative portrayal of the Muslim community. With the development of media technology in the West, the misrepresentation of Islam and Muslims reached the global masses, strengthening the propaganda of a backward and ominous Muslim world. In the book Covering Islam: How the Media and the Experts Determine How We See the Rest of the World, Said (1981) points out that although Muslims and Arabs are essentially discussed and apprehended either as oil suppliers or potential terrorists, the American media and its experts have failed to understand and explain the Arab and Muslim world to the American people (p. 26)

The continuous negative portrayal of Muslims in the media has led many Muslims to regard the media as the enemy for stereotyping them. The stereotypes against Muslims had been in-built in the US media and it is impossible to refute it. Furthermore, American media covers terrorism in a way that ignores what 'we' do and focuses on the behavior of 'them'. People's attitudes or impressions toward national or international issues are biased by the media representation of those issues. People don't really care about the truth rather are satisfied with the media representation. Western media takes this opportunity, fabricates the activities of Muslims, and links them directly to terrorism. Although many of those terrorist attacks were later found to be committed by Christian and Zionist fundamentalists, American media simply ignores the truth.

Jack Shaheen (2001) investigated the Arab stereotype, as shown in 900 films, in his voluminous documentary book Reel Bad Arabs: How Hollywood Vilifies a People where he scrutinized the slanderous history dating from the cinema's earliest days to the year 2001 and concluded that Hollywood rendered the Middle East in exotic terms that stoked ill feeling, distrust and loathing; he emphasized that Hollywood's presentation of Arabs as a pestilential threat was wildly alienating (Shaheen, 2). He elucidates the ways in which Hollywood has vilified the Arab community by representing 
them as money hungry, dangerous men or eroticized women or maidens. "He stresses the point that these stereotypes dangerously construct Arabs in limited roles that are politically motivated given American foreign policy within the Middle-East" (Aguayo, 2009, p. 43). This becomes especially problematic because Hollywood movies have international circulation which, consequently, negatively represents a community that is very diverse with different religious beliefs and political associations. Shaheen explains that Arabs have rarely been depicted as simple people with ordinary professions; he also implicitly suggests that the idea of depicting Arabs as different and inferior on screen is essential to the construction of the superior self of America.

"The image of Muslims as a dangerous threat in the Western world has been accentuated by the recent historical conflicts between the West and the Islamic Middle East, such as the Gulf War, the Salman Rushdie Affair, the bombing of New York City's World Trade Center and the Israeli-Palestinian conflict. The conflict reaches its peak after the terrible attack on the Twin Towers and the pentagon on September 11, 2001 and the subsequent war on Afghanistan and Iraq against terrorism" (qtd. in Abdullah, 2014, p. 7). According to Rubina Ramji (2005), most movies involving terrorism look at the subject from a US perspective, and the cultural expression of Muslims and Arabs in cinema reinforces and is reinforced by the structure of power relations between the Middle East and the United States. There is a change in traditional depictions of Muslims in some movies in the 1990s where Muslims are presented as hijackers, kidnappers and terrorist, replacing the stereotypical portrayal of the sheikh, oil-rich, ignorant and lusty despot. Muslims were started to be depicted as a threat to the civilized world and this perception reached its zenith after the 9/11.

\section{Depiction of Muslims as Terrorists in Pre-9/11 Films}

The film True Lies (1994), starring Arnold Schwarzenegger and directed by James Cameron, is a slick film perpetuating distorted images of Palestinians as dirty, demonic, and despicable people, and the reel portraits are so remote from reality as to give normal viewers uneasy feelings. Stalking America, the Palestinians plant nuclear bombs, detonating an atomic bomb in the Florida Keys. "Although the stale Arab-as-nuclear-terrorist image is a familiar one, True Lies is the first feature showing Arabs exploding a nuclear bomb inside the US" (Shaheen, 2001, p. 500). Cameron labels this Palestinian terrorist group, 'Crimson Jihad'; Crimson, meaning red, implies blood, and Cameron misuses the term 'Jihad', wrongly implying that Jihad means violence. Arabs in the film are shown not only as dangerous but also as clumsy and funny in their activities. The characters lack depth and seriousness. They are shown as irrational and having extreme hatred for everything American. There is no clear motivation for planting their nuclear weapons.

US special agent Harry (Arnold Schwarzenegger) receives the responsibility to prevent the 'dirty' Crimson Jihad from blowing up American cities. Jihad, which smuggles nuclear weapons out of a former Soviet country Kazakhstan, issues a warning: unless the US government withdraws its troops from Arab nations, they will detonate six nuclear weapons over American cities. In the film, Arabs are shown as mad murdering machines and blundering dullards, and are depicted in an offensive manner. Trying to launch a missile, the Palestinians kill one of their own. When Harry and another agent spot Arab assassin in Washington DC, they quip "Beavis and Butt-head". Trying to kill Harry, two Arabs shoot each other and a truck driver mistakenly runs over a fellow Arab. In order to save his son from Aziz, the terrorist leader, Harry flies off in a jet, attaches the villain to a missile and sends the missile to destroy a helicopter carrying some other terrorists. The director leaves no stone unturned to insult the Arab Muslims and the portrayal has been extremely vindictive and detrimental. Throughout the film, Arab Muslims are shown with evil intention but clumsy in their activities, and in this aspect this film differs from the film The Siege, which I will discuss next, where although Muslims are shown as a threat to the American society they seem to be very much adept in their work and aware of their responsibilities.

Harry is shown as a protector of his country and in order to serve his purpose he kills Arabs without considering anything else. When his wife Helen asks him "Have you ever killed anyone?" Harry replies, "Yeah, but they were all bad." It is very much understandable from such conversation that Arabs are vilified and are presented as boring. Now, if Arabs are criminal and terrorists, how we can label Harry who just might be working in a carnival, knocking off stuff with a gun and slaughtering multitudes for a laugh. The whole movie is full of unnecessary violence and distorted images of Muslim people. Some critics believe that the way Arab Muslims are depicted in the film is nothing but sheer racism. Troubled by the stereotypical images in True Lies, radio personality Casey Kasem wrote a letter to the key individuals associated with the film, mainly to James Cameron and Arnold Schwarzenegger, where he stated that the movie conveyed the sense of sheer racism and that it was an insult to anyone's intelligence, but, unfortunately, no one responded to him (Shaheen, 2001, p. 503).

Some viewers recognize that movies help shape public attitudes. In the fall of 1993, hate crimes were on the rise against Arab and Muslim Americans. This might happen because of the terrorist attack on the World Trade Center in 1993 and the involvement of Muslim terrorists with the attack. The way Hollywood films depict Muslims as terrorists and bad guys who are always anti-American, it is not unusual that American people will consider their Arab and Muslim neighbors as bad guys and anti-American. Although there is a disclaimer at the end of the film, True Lies: This film is a work of fiction and does not represent the actions or beliefs of a particular culture or religion, this kind of negative and derogatory portrayal of Muslims sometimes put them in danger and under suspicion in the real life, and we all are aware of the hate crimes against them. Because of this kind of intentional and/or unintentional negative portrayal, this religious community has suffered for a long time and is still suffering.

The Siege, released in 1998, is loosely based on a true terrorist attack. This movie continues to perpetuate the primitive, violent and aggressive Islam by finally developing the Islamic threat into a direct attack on the United States where Islamic fundamentalists threaten its greatest icons, the FBI building (One Federal Plaza) and New York City, in order to 
gain the release of an imprisoned sheikh. In fact, all Arab and Muslim Americans are suspected, and are persecuted for information regarding the homogenous threat of Islam. In order to smoke out the sleeper cells of New York Muslim people of Brooklyn are harassed, tortured, and treated like animals, and throughout the movie they are depicted as violent, inhuman, and dangerous.

Muslim terrorists in the film are shown holding hostages including children and elderly people in a bus to free their Sheikh. Without paying any heed to the attempt of negotiation by FBI agent Anthony Hubbard (Denzel Washington), the terrorists blow up the bus, and this bombing is put into the context of reality, with law enforcement officials stating that this has been the "worst terrorist bombing in the United States since Oklahoma City" leaving 25 people dead. Arab Muslims are then shown bombing a crowded Broadway theatre, killing the 'city's cultural leaders', and then trying to bomb a school and using children as hostages. When the FBI building is destroyed killing 200 people, the US chief of staff asserts that the Arab Muslims are "attacking our way of life". News coverage labels this as war, and images of angry Americans are shown calling Arab Muslims "towel-heads". Muslims become the victim of religious and cultural discrimination.

After enacting the War Powers Act and Martial law, General William Devereaux (Bruce Willis) takes charge of New York, and states that they are looking for 20 men but that they will search the 15,000 Arab and Muslim men living in Brooklyn to find the culprits. A large number of Muslim men between the ages of 14 to 30 are rounded up and put into detention camps behind barbed wire, while the army conducts house to house searches. Even Frank Haddad (Tony Shalhoub), an Arab American FBI agent who has been an American citizen for 20 years and who has been serving as an agent for 10 years, finds his twenty-year-old son interned in the camp because they are 'Shi'ite' and are therefore suspected.

One important aspect of The Siege is that it not only portrays Muslims as terrorists but also sheds some light on the role of US secret service behind their becoming terrorists. The film tells us how CIA recruits and trains Muslims to be terrorists and leave them when the business or alliance is complete. Hubbard and Elise Kraft (Annette Bening), a CIA agent now revealed to be an agent named Sharon Bridger, continue their investigation and capture a suspect, Tariq Husseini. It is discovered that she herself provided training and support to soldiers opposed to Saddam Hussein's government; she also worked with Samir (Sami Bouajila), who later becomes a teacher at a Brooklyn college, to recruit and train the supporters of the Sheikh. After the US cut their funding and left them exposed, she took pity on the few of them who had not yet been slaughtered by Hussein's forces, and helped them escape to the United States, ultimately leading to the present situation as they turn their covert bomb-making skills on the country that now holds their Sheikh.

The American Arabs felt insulted, discriminated, and were under attack. Despite their request to the film director to change the plot by substituting 'militiamen' for 'Islamic fundamentalists', it was released in its original form. Producerdirector Edward Zwick, in an HBO special on the making of The Siege, stated that the movie was in fact "based on truth, rather than a fiction thriller" (Shaheen, 2001, p. 432). Denzel Washington, who played the lead character, told a CNN reporter that "this is not a stereotypical view of any group of people; by any means...unfortunately, we're imitating life" (p. 432). Shaheen seems to assert strongly that Muslims are portrayed abusively and violently in the film which will tarnish their reputation and make them vulnerable in front of others.

In the film, different Islamic practices, such as reciting prayers from the Holy Quran, the ritual of washing the body before prayer, the call to prayer, and supplication were linked to terrorism and by doing so the director insulted the entire Muslim community. Every time someone performs the Muslim ablution, the ritual of washing different parts of body before five times prayer every day, that image is used as the signal of violence. Whereas to Muslims, ablution is the process of cleaning and purifying them, in this film it was always followed by something violent and ominous as if ablution was synonymous to violence and terrorism. The film seems to say that Muslims have total disregard for human life. Although the director tried to present a more balanced view through the character of Elise, who was truly sympathetic to and apprehensive of Muslim people and their religion itself, there was huge controversy regarding the treatment of Muslim characters. She was one who could understand Muslim culture and psychology very well, and who did not show any irreverence to Islam. She even had a love affair with Samir who constituted the final terrorist cell, and who later shot and killed her. Before she died, she could manage to recite certain lines of the second half of The Lord's Prayer, and could conclude with "In Sha Allah"-meaning 'if God wants'.

\section{Disastrous Consequences of 9/11 on Muslims and its Reflection in Literature}

The disastrous event of 9/11 is undoubtedly traumatic for Americans but the consequences of this event are even worse for the Muslim community. Because of the wrong-doings of very few Islamic fanatics who conduct suicide missions, peace-loving and simple-minded Muslim people suffer a lot from suspicion, hate crime, discrimination and psychological pressure. "Although stereotypes and discriminatory actions were nothing new to them, the post-9/11 backlash was relentless, overwhelming, and heartbreaking" (Bakalian \& Bozogmehr, 2009, p. 1). News and reports were broadcast where Muslims were shown in a negative and derogatory manner, and thus the media played a crucial role in shaping non-Muslim peoples' attitude towards and perception of Muslim people. They started to be viewed as either terrorists or sympathetic to terrorists and terrorism. Suddenly they were under focus and tight scrutiny, and found themselves the protagonists of many post-9/11 literary works and films.

Muslims were tortured severely in prisons and concentration camps because of their alleged involvement with terrorist activities. These developments, together with largely negative media coverage of Muslims, negative comments about Islam by many prominent political and religious leaders, various detrimental domestic policies against Muslims which 
significantly curtailed their civil and legal rights, and the aggressive foreign policies towards Middle-East which created very unsettling feelings among American Muslims may have produced greater distaste and hatred for Muslims among many citizens.

The social marginalization and persecution of Muslims wasn't merely a problem of rhetoric and public perception, but it manifested itself in physically violent ways. After 9/11, Muslims throughout America became the victims of violent backlash; people who appeared Middle-Eastern or had Arabic or Islamic sounding name became the scapegoats of some Americans' fury or revenge, and hate crimes and bias incidents spiked immediately. "In the days following September 11, 2001, many Arab and Muslim American organizations received threatening phone calls and slanderous e-mails, there were some confirmed cases of hate-motivated murder, and some Muslim shops were vandalized" (Bakalian \& Bozorgmehr, 2009, p. 3). More seriously, a few weeks after 9/11, the US government generated a series of initiatives and policies that targeted Middle Eastern and Muslim immigrant populations. Although apparently these administrative rule changes, orders, and laws aimed to stop terrorism, they legitimated the backlash in the eyes of American people.

As I mentioned earlier, after 9/11 suddenly the Muslim community came under sharp focus, and in many post-9/11 fictions they were portrayed as terrorists. Some novels, which may be called 'the second wave' of post-9/11 novels, "are more intently focused on the racial fear and anxiety sparked by the attacks and by the official response to them in the lives and minds of people previously inured to the effects of distant international affairs" (Banita, 2010, p. 242). The Reluctant Fundamentalist (2007) by Pakistani American writer Mohsin Hamid is an excellent post- 9/11 narrative dealing with the backlash of the traumatic event and the sense of identity of a Pakistani Muslim who, after being discriminated in every sphere of life in the US, leaves for his country and turns into a devout anti-American. Most significantly, his anti-Americanism is not shaped by his religious ideology but by his experience and assessment of America. Changez, a Princeton graduate, settled in America after getting a very good job and everything was going smoothly for him until the life-changing event of 9/11 took place. Changez could see the opposite side of America and was astonished to be viewed and assessed in very different and humiliating ways by various people. Mohsin Hamid, through the character of Changez, emphasizes the catastrophic aftermath of 9/11 on Muslims, and shows how this discrimination instigates people to be anti-American.

The novel is the story of Changez, who was a Princeton graduate and the high-earning, top trainee in an elite, highly lucrative American company, named Underwood Samson. Before September 11, 2001, Changez perfectly merges into the melting pot of New York City. His American dream is, however marred by the 9/11 attacks in New York. When the attacks on the World Trade Center take place, he is on a business trip to the Philippines and watches the news of the event on TV. At first perceiving the images as fictitious, Changez eventually reacts with a smile when realizing that the news is real. As the narrator tells the reader, seeing these pictures, Changez "was caught up in the symbolism of it all, the fact that someone had so visibly brought America to her knees" (Hamid, 2007, p. 83). It is hence the symbolic destruction of American meritocracy and of the center of global networks of commerce which left Changez, who apparently is no longer torn between his Pakistani and American self, smiling. This event makes him more conscious of his personal identity, and helps him find an end to his identity crisis as from now on he clearly identifies with his homeland Pakistan.

In spite of his controversial reaction to the attacks, Changez tries his best to pursue his career at Underwood Samson; however, he quickly realizes that things have changed for him significantly after the events. The world is no longer the same place, neither is the perception of people with presumed Muslim background. Changez is searched at the airport and separated from his American colleagues; he evokes anxious look when he finally manages to board the plane.

I flew to New York uncomfortable in my own face: I was aware of being under suspicion; I felt guilty; I tried therefore to be as nonchalant as possible; this naturally led to my becoming stiff and self-conscious (Hamid, 2007, p. 86).

Changez finds that his status has suddenly changed despite his education at a prestigious university and his lucrative job at a renowned company. The change is well represented by his conversations with an immigration officer after his arrival at the New York airport.

What is the purpose of your trip to the United States?" she asked me. "I live here," I replied. "That is not what I asked you, sir," she said. "What is the purpose of your trip to the United States?" Our exchange continued in much this fashion for several minutes. In the end I was dispatched for a secondary inspection in a room where I sat on a metal bench next to a tattooed man in handcuffs (Hamid, 2007, p. 86).

Changez also experienced a racist attack which distressed him completely. He was verbally attacked by a man who called Changez 'fucking Arab' and tried to pick a fight with him. The shocking and baseless confrontation just because of his ethnicity and appearance enraged him to such an extent that he considered using violence too. "I unlocked the boot, retrieving the tire iron from where it lay[....] and I felt, at that moment, fully capable of wielding it with sufficient violence to shatter the bones of his skull” (p. 134). The accident again proves to Changez that his social status makes no difference and that it cannot save him when it comes to racial prejudice. He was of course concerned of the rising tensions between Muslim people and the white American population. He also knew that Pakistani cabdrivers "were being beaten to within an inch of their lives; the FBI was raiding mosques, shops, even peoples' houses; Muslim men 
were disappearing, perhaps into shadowy detention centers for questioning or worse", but in his own words, he believed that similar things "invariably happened, in America as in all countries, to helpless poor, not to Princeton graduates earning eighty thousand dollars a year" (p. 107-108). The incident is just a signal that he was wrong.

Since returning to the US from Pakistan with the beard, Changez' identity is unexpectedly interpreted by his social surroundings in terms of his new-grown facial hair: "More than once, traveling on the subway - where I had always had the feeling of seamlessly blending in - I was subjected to verbal abuse by complete strangers, and at Underwood Samson I seemed to become overnight a subject of whispers and stares" (Hamid, 2007, p. 148). This quotation clearly shows the suspicion against people of a certain group after 9/11. The propagated images and discourse on terrorism and the attacks of $9 / 11$ thus already have their impact on people, influencing them in such a way that they perceive foreignlooking people with suspicion and presumption of possible terrorist ideas. This has happened in the novel as well as in real life after $9 / 11$.

Through the character of Changez, Mohsin Hamid demonstrates the post-9/11 discrimination and backlash against Muslims. Changez is embittered by the social discrimination, and racial and religious profiling in post-9/11 American society. He feels that his status in America will not be the same anymore; he feels looked down upon and his pride is hurt. He is further enraged by the 'War on Terror' and American policy in Asia in general; he decides to go back to Pakistan. The novel clearly shows the discriminatory attitudes towards Muslims and how these attitudes turn a person toward extreme anti-Americanism.

Unlike Changez, Jassim and Salwa, the protagonists of the novel Once in a Promised Land (2007) by Laila Halaby, are not the direct victims of the Twin Towers attack. The discrimination and racial profiling were not so severe against them as were against Changez. Although it can be said that the 9/11 attacks have contributed to the downfall of Jassim and Salwa, the most crucial problem for them was "the false inclusiveness promised by the American dream" (DeRosa, 2011, p. 3) whereas Changez was a direct victim of the collapse. In Halaby, we find family struggles, personal problems, adultery, and other issues hasten Jassim and Salwa's downfall, but in Hamid, it is the aftermath of 9/11 attack which single-handedly victimizes Changez and transforms him from a privileged position to a radical anti-American. We should not forget that like Changez, Jassim and Salwa were also financially successful but nothing could prevent them from their downfall.

Once in a Promised Land is the story of Jassim and Salwa Haddad, an Arab-American couple living in the USA, who suffers terribly because of the attack on the Twin Towers. Because of the event of 9/11 there is racial and religious profiling against them which lead to humiliation, mutual distance, collapse in their relationship, and ultimately to the disruption of their American dream. The post-9/11 atmosphere compels them to become self-conscious of their Arab identities. Salwa's thought of continuing life in post-9/11 America, her secret pregnancy, the consequent miscarriage, and the increasing anxiety create a distance between her and her husband. Meanwhile Jassim kills a boy in an accident and fails to confide it to Salwa. Unable to cope with the situation, Jassim becomes distracted and insincere to his official responsibilities. The couple hardly speaks with each other and both become involved in extra-marital affairs-Salwa with a colleague and Jassim with a waitress. Their increasing distance is caused by the attractive yet vague and false American dream.

We should not think that our protagonists suffer only because of their personal problems. Their downfall is initiated by the event of 9/11 and its shockwave. Like lots other Muslim people they also suffer from the backlash of 9/11. Jassim's staring at a motorbike for a long time at a shopping mall evokes suspicion in a teen-ager who ultimately calls security. In the bank, Salwa meets a client who asks her lots of questions regarding her background and later wants to be helped by "someone she can understand better" (Halaby, 2007, p. 114). Despite her material success, Salwa feels that there is something isolating in American culture. Because of the post-9/11 surveillance culture there is an FBI investigation of Jassim's accident which results in his being negligent to duty and ultimately his losing the job. "Most importantly after September 11, there is degradation in the status of Muslim Americans; they are branded not only as second-class citizens but also as social hazards" (Banita, 2010, p. 246).

There is a huge confusion in Jassim and Salwa about their dual identity and it is increased by the patriotic American people around them. The protagonists, who are educated, cultured, and financially well off but who are suddenly stickered as outsiders, are purposefully selected by Halaby to show the tragic downfall of Muslims in post-9/11 era. Jassim is suspected by the FBI as post-9/11 'terrorist searching' strategy, and the state's demand for as well as subjects' compliance to normative religious and political acquiescence comes out in full evidence during the investigation. "Their questions about Jassim's 'reaction to the war in Afghanistan', his opinion about 'Jordan's leadership', as well as his political activities outside the office affirm the recurring confluence among political dissent, Muslim identity, and terrorism in national security as well as public rhetoric after 9/11" (Conrey, 2011, p. 544). As Jassim is getting closer to his American dream, he seems to be forgetful of the possible danger he, as a Muslim, can encounter in post-9/11 America. He finds the idea illogical that Muslim children can be the victims of backlash; while analyzing his colleagues' strange attitude towards him, he dismisses the idea that they think him a terrorist. "He had as little connection to those men as they did, and there was no way he could accept that anyone would be able to believe him capable of sharing in their extremist philosophy" (Halaby, 2007, p. 23). Jassim's boss Marcuss understands that the suspicion evoked by Jassim in his clients because of his Muslim identity along with his lack of concern to his duty will be risky for his business. "This lack of concern is caused by Salwa's secret pregnancy and miscarriage, and by the accident. Because of these misfortunes, he starts to neglect his responsibilities and makes it easy for his boss to fire him. 
He ultimately makes it easy even for the FBI agents to diagnose him a potential threat for society" (Banita, 2010, p. 247).

Although the protagonists of the two post-9/11 novels that I have analyzed were from different countries and origin who resided in America, they all were victims of post 9/11 hatred, and racial and religious profiling. The brutal force of hatred and profiling did not spare a Princeton graduate like Changez who earned eighty thousand dollars per year. Jassim and Salwa are not as privileged as Chngez; they are ordinary human beings with vices and virtues whose downfall is initiated by the attacks on the Twin Towers but is quickened by their own wrongdoings. Still we cannot but sympathize with them the way we do with Changez as they all are victims of 9/11 backlash. Changez, Jassim, and Salwa could not tolerate the discrimination, were embittered by the way they were treated, decided to leave America, and settled in their own country.

\section{Conclusion}

Muslims have always been viewed with some degree of suspicion in the West. At times the media have tended to portray them with negative light. This happens because of the West's desire of cultural and political dominance over the East. Attitude towards Muslims and Islam started to shift when the presence of Muslims in the United States gained the attention of the larger society in the early 1980s. Different historical events such as the Iran hostage crisis during the Islamic revolution in 1979 and the TWA hijacking in Lebanon in 1985 were responsible for the deep-rooted prejudices in American society. In addition, the First Gulf War in 1991 and the first attack on the World Trade Center in New York in 1993 resulted in a rise of disciplinary action against Muslims and Muslim institutions. The Oklahoma City bombing in 1995 was an example of the scapegoating of Muslims even though investigation proved it to be the work of American Christians, and it is rather shocking that American people and media took it for granted, regardless of the actual sources of terrorism, that Muslims should be blamed and condemned. Movies and fictions often depict Muslims and Islam in a way that reflects their general perception among the wider population.

Next to the people who lost their life, Muslims were the worst sufferers of the 9/11attack on the Twin Towers. Although some Muslim fanatic accomplished the terrible task of destroying the towers, the entire Muslim community had to suffer for this. They suffered immediately from hate-crimes and discrimination although these were initially sporadic. Later, because of the US government's social, local and foreign policy, the Muslim community started to suffer from what can be labeled as 'institutionalized discrimination'. Muslims who had long been living in the US found themselves in a difficult and totally different situation, and discovered a different America. Their social rights were curtailed and they were under religious and racial profiling; lots of Muslims had to leave America because of the discrimination. Muslims who were suspected of having involvement with terrorism were tortured for information. Post-9/11 attitudes towards Muslims were reflected in literature and film. These were initially concerned with the trauma of the events although they later started to depict the effect of $9 / 11$ attacks on Muslims, their sufferings and the shattering of their dreams.

In novels and films Muslims are depicted in the same ways they are perceived of in real life by Westerners; in another word, they actually reflect historical realities. In both the pre-9/11 movies: True Lies and The Siege, Muslims are shown as funny, clumsy, and dangerous as they are considered by Westerners in real life. Again, the downfall of Jassim and Salwa in Once in a Promised Land, and the reversed life of Changez in The Reluctant Fundamentalist are not the mere imagination of the writers. The Reluctant Fundamentalist is too some extent an autobiography of the author Mohsin Hamid who, like Changez, had to go through difficulties in the post-9/11 America, and had to leave the country. It is true that these books and films have other themes like love, friendship, personal conflict, corporate life, Muslim community, American society, American dream, and so on, but when they speak about Muslims, it is all about stereotyping, vilification, discrimination, terrorism, racial and religious profiling, and hate crimes.

\section{References}

Abdullah, A. S. (2014). Ethnic Othering in True Lies. The Criterion, 5 (4), 1-10. Retrieved from: http://www.the criterion.com/V5/n4/Abu.pdf

Aguayo, M. (2009). Representations of Muslim bodies in The Kingdom: Deconstructing discourses in

Hollywood. Global Media Journal - Canadian Edition, 2(2), 41-56. Retrieved from: http://www.gmj.uottawa.ca/0902/v2i2_aguayo.pdf

Arti, S. (2007). The evolution of Hollywood's representation of Arabs before 9/11: The relationship between

political events and the notion of 'Otherness'. Journal of the MeCCSA Postgraduate Network, 1 (2), 1-20.

Austin, S. \& Cameron, J. (Producer), \& Cameron, J. (Director). (1994). True Lies [Motion Picture]. USA: $20^{\text {th }}$ Century Fox.

Bakalian, A. \& Bozorgmehr, M. (2009). Backlash 9/11: Middle Eastern and Muslim Americans respond.

California: University of California Press.

Banerjee, M. (2008). "Whiteness of a different color”? Racial profiling in John Updike's Terrorist. Neohelicon, 35(2), 13-28.

Banita, G. (2010). Race, risk, and fiction in the war on terror: Laila Halaby, Gayle Brandeis, and Michael 
Cunningham. Literature Interpretation Theory, 21 (4), 242-69.

Conrey, C. F. (2011). Arab American citizenship in crisis: Destabilizing representations of Arabs and Muslims in the US after 9/11. MFS Modern Fiction Studies, 57 (3), 532-555.

DeRosa, A. (2011). Nationalism and alterity in Laila Halaby and Jess Walter. Retrieved from: http://docs.lib.purdue.edu/cgi/viewcontent.cgi?article=1028\&context=revisioning

Halaby, L. (2007). Once in a promised land. Boston: Beacon.

Hamid, M. (2007). The reluctant fundamentalist. UK: Penguin.

Obst, L. and Zwick, E. (Producer), \& Zwick, E. (Director). (1998). The Siege [Motion Picture]. USA: $20^{\text {th }}$ Century Fox.

Ramji, R. (2005). From Navy Seals to The Siege: Getting to know the Muslim terrorist, Hollywood style. The Journal of Religion and Film, 9 (2). Retrieved From: https:/www.unomaha.edu/jrf/Vol9No2/ RamjiIslam.htm

Said, E. W. (1978). Orientalism. UK: Routledge \& Kegan Paul Ltd.

Said, E. W. (1981). Covering Islam: How the media and the experts determine how we see the rest of the world. UK: Routledge \& Kegan Paul Ltd.

Shaheen, J. G. (2001). Reel bad Arabs: How Hollywood vilifies a people. New York: Olive Branch. 